\title{
A study on community attitudes towards the mentally ill among youth in Gujarat
}

\author{
Bhavesh M. Lakdawala ${ }^{1}$, Ganpat K. Vankar ${ }^{2}$ \\ ${ }^{1}$ Associate Professor, Department of Psychiatry, GMERS Medical College and General Hospital, Gandhinagar, \\ Gujarat, India. \\ ${ }^{2}$ Professor, Department of Psychiatry, Sri Aurobindo Institute of Medical Sciences, Indore, Madhya Pradesh, India. \\ E-mail-dr_bmlakdawala@yahoo.co.in
}

\begin{abstract}
Background: Mental illness is a major contributor to global disease burden and this is expected to increase over years. In community mental illness has not been well understood by the lay persons, resulting in stigmatizing attitudes towards persons with mental illness and mentally ill. High mental health literacy which includes adequate knowledge and positive attitudes in college students towards psychiatric illnesses would benefit society at large.

Aims: Aim of the study was to assess knowledge and attitude of college students of Medical, Arts Faculties towards the mentally ill and socio-demographic correlates using CAMI subscales.

Methodology: Medical college and Arts colleges were surveyed Cross Sectionally regarding students' attitude towards psychiatric illness using the Community Attitude towards the Mentally Ill (CAMI) scale. Totally 1231 Students' responses were analyzed using appropriate statistical methods on SPSS version 15.0.

Results: On CAMI scale, students had positive attitudes for Benevolence subscale \& Community Mental Health Ideology Subscale. There was a mixed response on Social Restrictiveness subscale and negative attitude was found on Authoritarianism subscale in majority items. Significant differences were observed in attitude towards mentally ill by gender, faculty of education, family type and domicile.

Conclusions: These results suggest that widespread educational campaigns need to be implemented across the college students to increase knowledge about mental illness and reduce stigma towards mental illness and mentally ill persons by educational interventions and training which will benefit community at large.
\end{abstract}

Key Words: College Students, CAMI scale, mentally ill, Attitude.

(Paper received $-10^{\text {th }}$ October 2016, Peer review completed $-20^{\text {th }}$ November 2016, Accepted $-2^{\text {nd }}$ December 2016)

\section{INTRODUCTION}

Mental Health Literacy (MHL) includes the ability to recognize specific disorders, knowing how to seek mental health information; knowledge of risk factors and causes, of self treatments and of professional help available; and attitudes that promote recognition and appropriate help seeking [1]. Psychiatric disorders are universal [2]. Studies have shown that negative attitudes towards mental illness are widespread [3-7] and causes delay in seeking treatment [8]. Stigma and discrimination associated with mental illness and expressed by current and future mental health professionals results in the under use of mental health services [9]. Stigma leads to social exclusion and non-compliance. Several studies report that stigma is universal and involves not only lay persons but also various health professionals [10]. It is a myth that people with psychiatric illnesses are dangerous and violent [11-12]. Reasons for negative attitude are inaccurate information about mental illness, less contact with individuals with mental illness and low 
familiarity would be one of the most important reasons of this [13-14]. Knowledge and attitude of the undergraduate students of Medical, Psychology and Sociology fraternity towards mental health problems (MHPs) and mentally ill is of utmost importance as these individuals are going to be involved in the care of psychiatric patients during later years of their careers [15]. Psychiatry and Psychology as a discipline is felt to be given a step motherly treatment at the undergraduate level [16].

In most of the medical colleges Under Graduate (UG) teaching in Psychiatry is not given importance [1617]. In Arts colleges where undergraduate psychology and sociology courses are running, they have old curriculum and almost no exposure to people with psychiatric disorders. These all factors are responsible for lack of empathy and intolerant attitudes towards mentally ill in these groups of students. Research shows greater exposure to and working with mentally ill patients during medical training creates a positive attitude [18-19]. Main strategies for addressing psychiatric stigma and discrimination focus on protest, contact and education [20]. Short educational sessions can produce positive changes in students in knowledge and attitudes towards people with mental health problems [21-23].

Several Indian studies of medical students, medical professionals, and general public have concluded gaps in knowledge and stigma related to patients suffering from psychiatric disorders [15-17, 24-26]. Many international studies also found gaps in knowledge and stigma related to MHPs in professionals and in community $[5,11,22,27-29]$.

\section{AIMS OF THE STUDY}

The aim of the current study was to assess the attitudes of college students of three faculties - medical, psychology and sociology towards the mentally ill and compare different sociodemographic variables with Community Attitude towards the Mentally Ill (CAMI) subscales

\section{METHODOLOGY}

In Medical college and Arts colleges' students were surveyed regarding their attitudes towards psychiatric illness using the CAMI scale. Data of this paper are part of previous published paper on Mental Health Literacy amongst college students using National Health Service (NHS) Survey Questionnaire [30].

Institution's ethics committee permission was taken before conducting the study. Purpose of the study was informed and consent was taken from participants before participation in the study. Participants were ensured of the confidentiality of the information provided. Study questionnaire was filled up by participants. After this, an educational session for mental health awareness was taken for 1 hour.

Questionnaire comprised of Socio-demographic data, Community Attitude towards the Mentally Ill (CAMI) scale (English and Gujarati version). Gujarati version was standardized by the experts in the field of psychiatry.

\section{Community Attitude towards the Mentally Ill (CAMI) scale}

CAMI scale is a 40 -item questionnaire developed by Taylor and Dear [31]. Four separate subscales designed to measure attitudes towards the mentally ill were created. These scales represent specific dimensions Authoritarianism, Benevolence, Social Restrictiveness, and Community Mental Health Ideology (CMHI).

Authoritarianism refers to a view of mentally ill person as someone interfere who requires coercive handling. Benevolence corresponds to the paternalistic and sympathetic view of the mentally ill patients. Social restrictiveness refers to the belief that mentally ill patients are a threat to society and should be avoided. Community Mental Health Ideology concerns the acceptance of mental health services and mentally ill patients in the community. Each dimension in the CAMI scale is measured by 10 statements of which an equal numbers are worded positively (Pro item) and negatively (Anti item). A Likert type scale measures attitudes on a scale of five points from "strongly agree" (1) to "strongly disagree" (5). 


\section{STATISTICAL ANALYSIS}

Analysis was done using SPSS version 15 for windows. Qualitative data were analyzed by chi square test and quantitative data were analyzed by student's $t$ test and one-way ANOVA. Bivariate analysis was done for pro and anti items of all four subscales of CAMI. P value of $<0.05$ was considered statistically significant. We also compared association of socio-demographic variables like gender, year of education, faculties of study, domicile and family type with the 4 subscales of CAMI i.e. Authoritarianism, Benevolence, Social Restrictiveness and Community Mental Health Ideology.

\section{RESULTS}

Table 1: Socio-demographic characteristics of the respondents

\begin{tabular}{|c|c|}
\hline Variable & $\mathbf{N}(\%)$ \\
\hline $\begin{array}{l}\text { Gender } \\
\text { Female } \\
\text { Male }\end{array}$ & $\begin{array}{l}596(48.4) \\
635(51.6)\end{array}$ \\
\hline $\begin{array}{c}\text { Age } \\
\text { Range } \\
\text { Mean( SD) }\end{array}$ & $\begin{array}{c}17-25 \\
19.38(1.87)\end{array}$ \\
\hline $\begin{array}{l}\text { Marital Status } \\
\text { Unmarried } \\
\text { Engaged } \\
\text { Married }\end{array}$ & $\begin{array}{c}1151(93.5) \\
49(4.0) \\
31(2.5)\end{array}$ \\
\hline $\begin{array}{c}\text { Year of Education } \\
\text { First } \\
\text { Second } \\
\text { Third } \\
\text { Fifth }\end{array}$ & $\begin{array}{c}488(39.6) \\
368(29.9) \\
312(25.3) \\
63(5.1)\end{array}$ \\
\hline $\begin{array}{l}\text { Faculty of Study } \\
\text { Psychology } \\
\text { Sociology } \\
\text { MBBS }\end{array}$ & $\begin{array}{l}443(36.0) \\
130(10.5) \\
658(53.5)\end{array}$ \\
\hline $\begin{array}{c}\text { Residence } \\
\text { Ahmedabad (City) } \\
\text { Any Other }\end{array}$ & $\begin{array}{l}728(59.1) \\
503(40.9)\end{array}$ \\
\hline $\begin{array}{c}\text { Monthly Income Rupees } \\
19575 \text { or more } \\
9788 \text { to } 19575 \\
4894 \text { to } 9797 \\
\text { up to } 4893\end{array}$ & $\begin{array}{l}647(52.6) \\
209(17.0) \\
229(18.6) \\
146(11.8)\end{array}$ \\
\hline $\begin{array}{l}\text { Domicile } \\
\text { Urban } \\
\text { Rural }\end{array}$ & $\begin{array}{c}1022(83.0) \\
209(17.0)\end{array}$ \\
\hline $\begin{array}{l}\text { Religion } \\
\text { Hindu } \\
\text { Muslim } \\
\text { Others }\end{array}$ & $\begin{array}{c}1147(93.2) \\
49(4.0) \\
35(2.9)\end{array}$ \\
\hline
\end{tabular}




\section{Students' attitude towards mentally ill on CAMI subscales}

Table 2 - Students' attitude towards mentally ill on Authoritarianism subscale

\begin{tabular}{|c|c|}
\hline \multicolumn{2}{|l|}{ Authoritarianism } \\
\hline Item & $(\%)$ \\
\hline $\begin{array}{l}\text { As soon as a person shows signs of mental disturbance, he should be hospitalized. } \\
\text { (Strongly Agree/Agree) (Pro) }\end{array}$ & 51.5 \\
\hline Mental illness is an illness like any other.(Strongly Disagree/Disagree) (Anti) & 48.9 \\
\hline $\begin{array}{l}\text { There is something about the mentally ill that makes it easy to differentiate them from } \\
\text { normal people. (Strongly Agree/Agree) ((Pro) }\end{array}$ & 55.8 \\
\hline $\begin{array}{l}\text { Less emphasis should be placed on protecting the public from the mentally ill. } \\
\text { (Strongly Disagree/Disagree) (Anti) }\end{array}$ & 37.0 \\
\hline $\begin{array}{l}\text { Mental patients need the same kind of control and discipline as a young child. } \\
\text { (Strongly Agree/Agree) (Pro) }\end{array}$ & 70.5 \\
\hline $\begin{array}{l}\text { The mentally ill should not be treated as outcasts of society. } \\
\text { (Strongly Disagree/Disagree) (Anti) }\end{array}$ & 11.1 \\
\hline $\begin{array}{l}\text { The best way to handle the mentally ill is to keep them behind locked doors. } \\
\text { (Strongly Agree/Agree) (Pro) }\end{array}$ & 4.7 \\
\hline $\begin{array}{l}\text { Mental hospitals are an outdated means of treating the mentally ill. } \\
\text { (Strongly Disagree/Disagree) (Anti) }\end{array}$ & 36.9 \\
\hline $\begin{array}{l}\text { One of the main causes of mental illness is a lack of self-discipline and will power. } \\
\text { (Strongly Agree/Agree) (Pro) }\end{array}$ & 54.8 \\
\hline Virtually anyone can become mentally ill.( Strongly Disagree/Disagree) (Anti) & 12.0 \\
\hline
\end{tabular}

Table 3 - Students attitude on the Benevolence sub-scale

\begin{tabular}{|lc|}
\hline \multicolumn{1}{|c|}{ Benevolence } & (\%) \\
\hline Item & 75.6 \\
\hline $\begin{array}{l}\text { More tax money should be spent on the care and treatment of the mentally ill. } \\
\text { (Strongly Agree/Agree) (Pro) }\end{array}$ & 85.9 \\
\hline $\begin{array}{l}\text { The mentally ill are a burden on society. } \\
\text { (Strongly Disagree/Disagree) (Anti) }\end{array}$ & 67.2 \\
\hline $\begin{array}{l}\text { The mentally ill have for too long been the subject of ridicule. } \\
\text { (Strongly Agree/Agree) (Pro) }\end{array}$ & 83.7 \\
\hline $\begin{array}{l}\text { Increased spending on mental health services is a waste of tax money. } \\
\text { (Strongly Disagree/Disagree) (Anti) }\end{array}$ & 88.0 \\
\hline $\begin{array}{l}\text { We need to adopt a far more tolerant attitude toward the mentally ill in our society. } \\
\text { (Strongly Agree/Agree) (Pro) }\end{array}$ & \\
\hline
\end{tabular}


There are sufficient existing services for the mentally ill.

(Strongly Disagree/Disagree) (Anti)

Our mental hospitals seem more like prisons than like places where the mentally ill can be 46.5 cared for. (Strongly Agree/Agree) (Pro)

The mentally ill do not deserve our sympathy.

(Strongly Disagree/Disagree)(Anti)

We have the responsibility to provide the best possible care for the mentally ill.

(Strongly Agree/Agree) (Pro)

It is best to avoid anyone who has mental problems.

(Strongly Disagree/Disagree) (Anti)

Table 4 - Students' attitude towards mentally ill on Social restrictiveness subscale

\begin{tabular}{|c|c|}
\hline \multicolumn{2}{|l|}{ Social Restrictiveness } \\
\hline Item & $(\%)$ \\
\hline $\begin{array}{l}\text { The mentally ill should be isolated from the rest of the community. } \\
\text { (Strongly Agree/Agree) (Pro) }\end{array}$ & 89.9 \\
\hline $\begin{array}{l}\text { The mentally ill are far less of a danger than most people suppose. } \\
\text { (Strongly Agree/Agree) (Anti) }\end{array}$ & 37.5 \\
\hline $\begin{array}{l}\text { A woman would be foolish to marry a man who has suffered from mental illness, even though } \\
\text { he seems fully recovered. } \\
\text { (Strongly Disagree/Disagree) (Pro) }\end{array}$ & 77.9 \\
\hline $\begin{array}{l}\text { No one has the right to exclude the mentally ill from their neighborhood. } \\
\text { (Strongly Agree/Agree) (Anti) }\end{array}$ & 80.5 \\
\hline $\begin{array}{l}\text { I would not want to live next door to someone who has been mentally ill. } \\
\text { (Strongly Disagree/Disagree) (Pro) }\end{array}$ & 63.6 \\
\hline $\begin{array}{l}\text { Mental patients should be encouraged to assume the responsibilities of normal life. } \\
\text { (Strongly Agree/Agree) (Anti) }\end{array}$ & 81.2 \\
\hline $\begin{array}{l}\text { Anyone with a history of mental problems should be excluded from taking public office. } \\
\text { (Strongly Disagree/Disagree) (Pro) }\end{array}$ & 53.6 \\
\hline $\begin{array}{l}\text { The mentally ill should not be denied their individual rights. } \\
\text { (Strongly Agree/Agree) (Anti) }\end{array}$ & 74.1 \\
\hline $\begin{array}{l}\text { The mentally ill should not be given any responsibility. } \\
\text { (Strongly Disagree/Disagree) (Pro) }\end{array}$ & 49.9 \\
\hline $\begin{array}{l}\text { Most women who were once patients in a mental hospital can be trusted as baby sitters. } \\
\text { (Strongly Agree/Agree) (Anti) }\end{array}$ & 35.0 \\
\hline
\end{tabular}


Table 5 - Students' attitude towards mentally ill on community mental health ideology subscale

\begin{tabular}{|c|c|}
\hline Community Mental Health Ideology (CMHI) & \\
\hline Item & (\%) \\
\hline $\begin{array}{l}\text { The best therapy for many mental patients is to be part of a normal community. } \\
\text { (Strongly Agree/Agree) (Pro) }\end{array}$ & 82.8 \\
\hline $\begin{array}{l}\text { Locating mental health facilities in a residential area downgrades the neighborhood. } \\
\text { (Strongly Disagree/Disagree) (Anti) }\end{array}$ & 74.4 \\
\hline $\begin{array}{l}\text { As far as possible mental health services should be provided through community-based } \\
\text { facilities. (Strongly Agree/Agree) (Pro) }\end{array}$ & 74.1 \\
\hline $\begin{array}{l}\text { Having mental patients living within residential neighborhoods might be good therapy, but } \\
\text { the risks to residents are too great. } \\
\text { (Strongly Agree/Agree) (Anti) }\end{array}$ & 45.9 \\
\hline $\begin{array}{l}\text { Residents should accept the location of mental health facilities in their neighborhood to } \\
\text { serve the needs of the local community. } \\
\text { (Strongly Agree/Agree) (Pro) }\end{array}$ & 85.7 \\
\hline $\begin{array}{l}\text { Local residents have good reason to resist the location of mental health services in their } \\
\text { neighborhood. (Strongly Disagree/Disagree) (Anti) }\end{array}$ & 60.6 \\
\hline $\begin{array}{l}\text { Locating mental health services in residential neighborhoods does not endanger local } \\
\text { residents. (Strongly Agree/Agree) (Pro) }\end{array}$ & 58.7 \\
\hline $\begin{array}{l}\text { Mental health facilities should be kept out of residential neighborhoods. } \\
\text { (Strongly Disagree/Disagree) (Anti) }\end{array}$ & 51.8 \\
\hline $\begin{array}{l}\text { Residents have nothing to fear from people coming into their neighborhood to obtain } \\
\text { mental health services. } \\
\text { (Strongly Agree/Agree) (Pro) }\end{array}$ & 73.0 \\
\hline $\begin{array}{l}\text { It is frightening to think of people with mental problems living in residential } \\
\text { neighborhoods. (Strongly Disagree/Disagree) (Anti) }\end{array}$ & 58.8 \\
\hline
\end{tabular}

\section{Scores on all CAMI subscale and reliability measures:}

Table 6 - Student scores on the four subscale and reliability measure

\begin{tabular}{|ccccc|}
\hline Subscale & Range & Mean & SD & $\begin{array}{c}\text { Cronbach's } \\
\text { Alpha }\end{array}$ \\
\hline Authoritarianism & $16-45$ & 31.71 & 4.37 & 0.335 \\
\hline Benevolence & $10-44$ & 20.95 & 5.09 & 0.618 \\
\hline Social Restrictiveness & $15-50$ & 37.12 & 5.34 & 0.630 \\
\hline Community Mental Health Ideology & $10-45$ & 22.78 & 5.28 & 0.567 \\
\hline
\end{tabular}

Reliability of each subscale was good except Authoritarianism subscale ( Crohnbach's Alpha $=0.335$ ). Bivariate Analysis (Spearman's Correlation) of Pro and Anti Items of Subscales on all the four subscales ranged from 0.092 to 0.383 with high statistical significance $(\mathrm{p}<0.0001)$. This shows high reliability of each subscale in their Pro and Anti items. 
Socio-demographic variables and Attitude

Table 7 - Gender comparison on the four subscales (Females=596, Males $=635$ )

\begin{tabular}{|c|c|c|c|c|c|}
\hline Subscale & $\begin{array}{l}\text { Gender } \\
\text { (N) }\end{array}$ & Mean & SD & $\begin{array}{c}\text { F } \\
\text { (By one-way } \\
\text { ANOVA) }\end{array}$ & $\mathbf{P}$ value \\
\hline Authoritarianism & $\begin{array}{c}\text { Females } \\
\text { Males }\end{array}$ & $\begin{array}{l}31.87 \\
31.56\end{array}$ & $\begin{array}{l}4.50 \\
4.24\end{array}$ & 1.549 & 0.214 \\
\hline Benevolence & $\begin{array}{c}\text { Females } \\
\text { Males }\end{array}$ & $\begin{array}{l}20.56 \\
21.32\end{array}$ & $\begin{array}{l}4.90 \\
5.23\end{array}$ & 6.900 & 0.009 \\
\hline Social Restrictiveness & $\begin{array}{c}\text { Females } \\
\text { Males }\end{array}$ & $\begin{array}{l}37.73 \\
36.55\end{array}$ & $\begin{array}{l}5.39 \\
5.23\end{array}$ & 15.193 & $<0.0001$ \\
\hline $\begin{array}{l}\text { Community Mental } \\
\text { Health Ideology }\end{array}$ & $\begin{array}{c}\text { Females } \\
\text { Males }\end{array}$ & $\begin{array}{l}22.50 \\
23.06\end{array}$ & $\begin{array}{l}5.29 \\
5.26\end{array}$ & 3.466 & 0.063 \\
\hline
\end{tabular}

Males had significantly higher benevolence score than females On the contrary; females had significantly higher social restrictiveness score than males.

Table 8 - Compares Attitude subscale score of the three faculties

\begin{tabular}{|c|c|c|c|c|c|}
\hline Subscale & $\begin{array}{l}\text { Faculty of Study } \\
\text { (N) }\end{array}$ & Mean & SD & $\begin{array}{c}\text { F } \\
\text { (By one-way } \\
\text { ANOVA) }\end{array}$ & P value \\
\hline \multirow[t]{3}{*}{ Authoritarianism } & Psychology & 30.96 & 4.30 & 16.150 & $<0.0001$ \\
\hline & Sociology & 30.95 & 4.32 & & \\
\hline & Medical & 32.36 & 4.33 & & \\
\hline \multirow[t]{3}{*}{ Benevolence } & Psychology & 21.77 & 5.46 & 14.078 & $<0.0001$ \\
\hline & Sociology & 21.75 & 4.74 & & \\
\hline & Medical & 20.24 & 4.78 & & \\
\hline \multirow[t]{3}{*}{ Social Restrictiveness } & Psychology & 36.72 & 5.35 & 4.389 & 0.013 \\
\hline & Sociology & 36.40 & 5.25 & & \\
\hline & Medical & 37.53 & 5.61 & & \\
\hline Community Mental & Psychology & 22.95 & 5.17 & 2.120 & 0.120 \\
\hline \multirow[t]{2}{*}{ Health Ideology } & Sociology & 23.50 & 5.83 & & \\
\hline & Medical & 22.54 & 5.23 & & \\
\hline
\end{tabular}


Medical students had significantly higher Authoritarianism and Social Restrictiveness score than psychology and sociology students. On the contrary, psychology students had significantly higher Benevolence score than sociology and medical students.

\section{Level (Year) of study and Attitude}

The CAMI subscale score of the students were compared on the basis of their level (year) of the course. There were no statistically significant differences in Authoritarianism, Benevolence, Social Restriction, and CMHI scores by year in which students studying. Thus studying in higher standard doesn't find to have any impact on attitude to mentally ill.

\section{Family constellation and Attitude}

Nuclear family type had statistically significant higher mean score than joint family for Authoritarianism subscale (32.24 vs. 31.11). Joint family type had statistically significant higher score than nuclear family type on Social Restrictiveness subscale (37.67 vs. 36.49). For CMHI subscale no statistically significant difference was found by family type.

\section{Domicile and attitude}

Urban respondents had more authoritarian attitude than rural respondents $(p=0.034)$. On the other three subscales there was no statistically significant difference.

Table 9 - Perception of Usefulness of Different Types of Treatment and Faculty

\begin{tabular}{|c|c|c|c|c|c|c|}
\hline $\begin{array}{l}\text { Usefulness of } \\
\text { Type of } \\
\text { Treatment }\end{array}$ & $\begin{array}{l}\text { Level of } \\
\text { Agreement }\end{array}$ & $\begin{array}{l}\text { Psychology } \\
\text { Students } \\
(\mathrm{N}=443)\end{array}$ & $\begin{array}{l}\text { Sociology } \\
\text { Students } \\
(\mathbf{N}=130)\end{array}$ & $\begin{array}{l}\text { Medical } \\
\text { Students } \\
(\mathrm{N}=658)\end{array}$ & $\begin{array}{l}\text { Chi } \\
\text { Square }\end{array}$ & P value \\
\hline \multirow[t]{5}{*}{ Medicines } & Strongly Agree & $60(13.5)$ & $15(11.5)$ & $123(18.7)$ & 67.9 & $<0.0000001$ \\
\hline & Agree & $127(28.7)$ & $37(28.5)$ & $295(44.9)$ & & \\
\hline & Neutral & $124(28.0)$ & $38(29.2)$ & $125(19.0)$ & & \\
\hline & Disagree & $97(21.9)$ & $30(23.1)$ & $101(15.4)$ & & \\
\hline & Strongly Disagree & $35(7.9)$ & $10(7.7)$ & $14(2.0)$ & & \\
\hline \multirow{5}{*}{$\begin{array}{l}\text { Psychotherapy } \\
\text { (Counseling) }\end{array}$} & Strongly Agree & $135(30.6)$ & $28(21.5)$ & $357(54.3)$ & 136.8 & $<0.0000001$ \\
\hline & Agree & $189(42.9)$ & $60(46.2)$ & $251(38.2)$ & & \\
\hline & Neutral & $67(15.2)$ & $30(23.1)$ & $35(5.3)$ & & \\
\hline & Disagree & $42(9.5)$ & $9(6.9)$ & $10(1.5)$ & & \\
\hline & Strongly Disagree & $10(1.8)$ & $3(2.3)$ & $5(0.6)$ & & \\
\hline
\end{tabular}

There was a statistically significant difference between medical and nonmedical students regarding belief of usefulness of medicines and psychotherapy in MHPs in favor of medical students $(\mathrm{P}<0.0000001)$.

\section{DISCUSSION}

\section{Students' attitude towards mentally ill on CAMI subscales}

In this study, the students had positive attitudes for Benevolence subscale and Community Mental Health Ideology subscale. There was a mixed response on Social Restrictiveness subscale and negative attitude was found on Authoritarianism subscale in majority items. 
There are several community studies on attitude towards mentally ill using CAMI scale $[13,27]$. There are also studies in medical and pharmacy students using instruments specifically in the context of professional courses [32-39].

In this study, more Authoritarianism score in students was similar to the study done in the past [27]. This may be interpreted as participants may believe in coercive handling of mentally ill. In this study, the attitudes were more positive on Benevolence and CMHI subscales; while in Dominic study attitudes were positive on Benevolence subscale but negative attitudes were on CMHI subscale. These suggest that students had sympathetic view towards mentally ill. Moreover they were accepting mental health services and mentally ill in community. Finding regarding Social Restrictiveness were mixed. Some felt that mentally ill are threat to society and should be avoided; while some had positive attitude. In Dominic study attitudes on Social Restrictiveness subscale were negative.

\section{Authoritarianism Subscale}

On statement that "Virtually anyone can become mentally ill"

In our study, 12\% participants disagreed while in NHS survey [29], 91\% agreed; in Ireland survey [28], $85 \%$ agreed and in Nigeria study [27], 15.4\% disagreed. This indicates almost similar results in all studies.

On statement that "As soon as person shows signs of Mental Illness, he should be hospitalized"

In our study, $51.5 \%$ participants agreed while in NHS survey $21 \%$ agreed and in Nigeria study $62 \%$ agreed. This shows negative attitudes in the current and the Nigeria study.

On statement that "Mental hospitals are an outdated means of treating people with MI

In our study $36.9 \%$ disagreed while in NHS survey $34 \%$ agreed and in Nigeria study $78 \%$ disagreed. This indicates more positive attitude than other studies but still substantial proportion believe that Mentally Ill (MI) should be treated in mental hospitals which shows that they are ignorant about community based psychiatric treatment movement

On statement that "There is something about the mentally ill that makes it easy to differentiate them from normal people."

In this study $55.8 \%$ agreed while in NHS survey $22 \%$ agreed and in Nigeria study $75 \%$ agreed. This shows negative attitudes in this and Nigeria study.

On statement that "Mental illness is an illness like any other"

In this study, $48.9 \%$ disagreed while in NHS survey $77 \%$ agreed and in Nigeria study $40 \%$ disagreed. This shows negative attitude of participants in this study.

\section{Benevolence subscale}

On the statement "We need to adopt a far more tolerant attitude toward the mentally ill in our society."

In Our study, $88 \%$ agreed while in NHS survey $86 \%$ agreed and in Nigeria study only $4.8 \%$ disagreed. This shows positive attitude in all mentioned studies.

On the statement "It is best to avoid anyone who has mental problems."

In Our Study, 66.5\% Disagreed and in Nigeria study 16.3\% agreed. This also shows positive attitude but still substantial numbers of participants believed that people with mental problems should be avoided which is worrying factor.

\section{Social Restrictiveness subscale}

On the statement "The mentally ill should not be denied their individual rights."

In our study, $74.1 \%$ agreed while in Ireland survey $81 \%$ agreed and in Nigeria study $82.7 \%$ disagreed. This shows more negative attitude in Nigerian study than other two studies.

\section{On statement that "I would not want to live next door to someone who is MI"}

In our study $63.6 \%$ disagreed while in NHS survey only $11 \%$ agreed and in Nigeria study $22.1 \%$ agreed.

This shows more negative attitude in our study than other two studies. 
On statement that "The mentally ill are far less of a danger than most people suppose"

In our study, $37.5 \%$ agreed while in NHS study $62 \%$ agreed and Nigerian study $26 \%$ disagreed. This shows that substantial proportion of participants in our study believe that mentally ill are dangerous.

\section{Community Mental Health Ideology subscale}

On statement that "Locating MH facilities in a residential area downgrades the neighborhood"

In our study, $74.4 \%$ disagreed while in NHS survey $17 \%$ agreed and in Nigeria study $31.7 \%$ disagreed. This shows more negative attitude in Nigerian study than other two studies.

On statement that "As far as possible MH services should be provided through community based facilities"

In our study, $74.1 \%$ agreed while in NHS survey $74 \%$ agreed and in Nigerian study only $13.5 \%$ disagreed. This shows positive attitude in all three studies.

The results indicate that the stigmatizing attitudes to the mentally ill are widespread in student population of medical, psychology and sociology fraternity, who are future mental health professionals. So there is an immediate need to change psychiatry curriculum and training in undergraduate students in all faculties so that positive and tolerant attitude can be learnt from starting of the study only [15-16, 40].

\section{Scores on all CAMI subscale and reliability measures:}

Reliability of each subscale was good except Authoritarianism subscale. This was similar to other studies using the CAMI scale $[14,41]$.

\section{Socio-demographic variables and Attitude:}

Community attitudes to mentally ill people have been shown to vary with the socio-demographic characteristics of the population [42-44].

Various authors have found that similar socio-demographic factors such as age, gender, education, domicile and family type determine attitudes [41-42]. However, their relative strengths differ. These differences may, in part, be due to the different populations under study. In our study, all factors like gender, faculty of education, domicile and family type except year of study exerted significant independent effect on different subscale of CAMI.

We found medical students had higher Authoritarianism and Social restrictiveness score compared to psychology and sociology students. While psychology students had significantly higher Benevolence score compared to other two groups. But year of education had no effect on any subscale.

\section{Gender and Attitude}

More specifically males had significantly higher benevolence score than females. On the contrary; females had significantly higher social restrictiveness score than males. In Nigerian study no significant difference was found by gender [27].

\section{Faculty of study and Attitude}

More specifically Medical students had significantly higher Authoritarianism score than psychology and sociology students; In addition, Medical students had significantly higher social restrictiveness score than psychology and sociology students. On the other hand, Psychology students had significantly higher benevolence score than sociology and Medical students. Researchers have commented that there is a need to specify the method by which psychology topics are taught in a practically oriented manner in medical colleges so that more stigmatizing attitudes can be corrected [40].

\section{Level (Year) of study and Attitude}

There were no statistically significant differences in Authoritarianism, Benevolence, Social Restriction and CMHI scores by year in which students studying. Thus studying in higher standard doesn't automatically change attitude to mentally ill.

\section{Family constellation and Attitude}

Nuclear family type had statistically significant higher score than joint family for Authoritarianism subscale. Joint family type had statistically significant higher score than nuclear family type on social restrictiveness subscale. For CMHI subscale no statistically significant difference was found by family type. So mixed attitudes were found in regards to family type. 


\section{Domicile and attitude}

Urban respondents had more Authoritarian attitude than rural respondents $(p=0.034)$. On the other three subscales there was no statistically significant difference. Authors have reported that rural Indians showed higher stigma score than urban Indians which is contrast to our study which may be because different study population [24].

\section{Perception of Usefulness of Different Types of Treatment and Faculty}

Medication usefulness considered by medical students can be understood but nonmedical students' (psychology and sociology) higher disagreement regarding psychotherapy (counseling) usefulness is a matter of concern. There was no statistically significant difference between psychology and sociology students.

\section{Strength and Limitation of the study}

- This is the first Indian study to use CAMI scale in Indian population.

- Students were also given education session of 1 hour on Mental Health after collecting data which can improve their knowledge and attitude.

- The study doesn't reflect the attitude towards MHP of general community.

\section{Future Implications}

- Similar study can be conducted in general community, in people with all age group and different educational background using CAMI scale.

- These results suggest that widespread educational campaigns need to be implemented across the college students to increase knowledge about mental illness and reduce stigma towards mental illness and mentally ill persons by educational interventions and training which will benefit community at large.

\section{CONCLUSIONS}

- We found significant negative attitude in students of all faculties particularly in area of Authoritarianism and Social Restrictiveness subscales.

- Significant differences were observed in attitude towards mentally ill by gender, faculty of education, family type and domicile.

- A perception of mentally ill as a violent person was found.

- These all signify that efforts are needed to improve knowledge and attitude in college students' population who are future mental health professionals.

\section{REFERENCES}

1. Jorm AF, Korten AE, Jacomb PA, Christensen H, Rodgers B, Pollitt P. "Mental health literacy": a survey of the public's ability to recognise mental disorders and their beliefs about the effectiveness of treatment. MJA 1997;166(4):182-6.

2. WHO available from http://www.who.int.whr2001//. The world health report 2001. Mental health:new understanding, new hope. Geneva:WHO 2001.

3. Crisp AH, Gelder MG, Rix S, Meltzer HI, Rowlands OJ. Stigmatisation of people with mental illnesses. Br J Psychiatry 2000;177:4-7.

4. Caldwell TM, Jorm AF. Mental health nurses' beliefs about interventions for schizophrenia and depression: a comparison with psychiatrists and the public.Aust N Z J Psychiatry 2000;34:602-11..

5. Gureje O, Lasebikan VO, Ephraim-Oluwanuga O, OlleyBO,Kola L. Community study of knowledge of and attitude to mental illness in Nigeria. Br J Psychiatry 2005;186:436-41.

6. Jorm AF, Korten AE, Jacomb PA, et al. Helpfulness of interventions for mental disorders: beliefs of health professionals compared with the general public.Br J Psychiatry 1997;171:233-7.

7. Link BG, Phelan JC, Bresnahan M, Stueve A, Pescosolido BA. Public conceptions of mental illness: labels, causes, dangerousness, and social distance. Am J Public Health 1999; 89:1328-33. 
8. Byrne P. Stigma of mental illness and ways of diminishing it. Adv Psychiatr Treatment 2000;6:65-72.

9. Esters I, Cooker P, Ittenbach R. Effects of a unit of instruction in mental health on rural adolescents' conceptions of mental illness and attitudes about seeking help, in U.K. Adolescence 1998;33(130):469-76.

10. Murthy RS. Stigma is universal but experiences are local. World Psychiatry 2002; 1(1):28.

11. Jorm AF. Mental health literacy. Public knowledge and beliefs about mental disorders. Br J Psychiatry 2000; 177:396-401.

12. Sadik S, Bradley M, Al-Hasoon S, Jenkins R. Public perception of mental health in Iraq. Int J Ment Health Syst 2010;4:26

13. Wollf G, Pathare S, Craig T, Leff J. Community attitudes to mental illness. Br J Psychiatry 1996;168:183-90.

14. Corrigan PW, Green A, Lundin R, Kubiak MA, Penn DL. Familiarity with and social distance from people who have serious mental illness. Psychiatr Serv 2001;52:953-8.

15. Chawla JM, Balhara YP, Sagar R, Shivprakash. Undergraduate medical students' attitude toward psychiatry: A cross-sectional study. Indian J Psychiatry 2002;54:37-40.

16. Trivedi JK, Dhyani M. Undergraduate psychiatric education in south Asian countries. Indian J Psychiatry, 2007;49:163-5.

17. Murthy RS, Khandelwal S. Undergraduate training in psychiatry: World prespective. Indian J Psychiatry 2007;49:169-74.

18. Kuhnigk O, Strebel B, Schilauske J, Jueptner M. Attitudes of medical students towards psychiatry: Effects of training courses in psychiatry, psychiatric experience and gender.Adv Health Science Educ Theory Pract 2007;12:87-101.

19. Reddy JP, Tan SM, Azami MT, Shaharom MH, Rosdinom R, Maniam T. Effect of clinical posting in psychiatry on attitudes of medical students towards psychiatry and mental illness in a Malaysian medical school. Ann Acad Med Singapore 2005;34:505-10.

20. Chambers M, Guise V, Välimäki M. Nurses' attitudes to mental illness: a comparison of a sample of nurses from five European countries. Int J Nurs Stud 2010;47:350-62.

21. Pinfold V, Toulmin H, Thornicroft G, Huxley P, Farmer P, Graham T. Reducing psychiatric stigma and discrimination: evaluation of educational interventions in UK secondary schools. Br J Psychiatry 2003; 182:342-6.

22. Kitchener BA, Jorm AF: Mental health first aid training for the public: evaluation of effects on knowledge, attitudes and helping behavior. BMC Psychiatry 2002; 2:10.

23. Lauber C, Gross VA, Fritschi N, Stulz N , Rössler W. Mental health literacy in educational elite - an online survey among university students. BMC Public Health 2005; 5:44.

24. Jadhav S, Littlewood R, Ryder AG, Chakraborty A, Jain S, Barua M. Stigmatization of severe mental illness in India: Against the simple industrialization hypothesis. Indian J Psychiatry 2007;49:189-94

25. Kuruvilla PK, John JK. Knowledge and attitude about psychiatric illness among interns. Indian J Psychiatry. 1991;33(1):11-5.

26. Armstrong G, Kermode M, Shoba R, Sujatha S, Chandra P, Jorm AF. A mental health training program for community health workers in India: impact on knowledge and attitudes. Int $\mathrm{J}$ Ment Health Syst 2011;5:17

27. Dominic IU, Festus A. Stigmatizing attitudes towards the mentally ill: A survey in a Nigerian university teaching hospital. South Afr J Psychiatry 2010;16:56-60.

28. Health Service Executive: Mental Health in Ireland: Awareness and Attitudes 2007. ISBN 978-0-9553854-2-1

29. Attitude to mental illness, NHS (National Health Service) 2011 Survey Reports; Version 1; Date of Publication: 8 June 2011: NHS Information Center Mental Health and Community.

30. Lakdawala B, Vankar G K. Mental Health Literacy amongst college students: a community based study. Indian J Ment Health 2016;3(3):342-50.

31. Taylor SM, Dear MJ. Scaling community attitudes toward the mentally ill. Schizoph Bull 1981;7:225-40.

32. Pillai SK, Hatim AS, Jesjeet SG, Jambunathan ST. Psychiatric Posting in Final Year Medical Students: Do Attitudes Change? Malaysian J Psychiatry 2006;15(2):26-34.

33. Mukherjee R, Fialho A, Wijetunge A, Checkinski K, Surgenor T. The stigmatisation of psychiatric illness; the attitudes of medical students and doctors in a London teaching hospital. Psychiatric Bull 2002;26:178-81.

34. Amber V, Reza M. Peer-Level Patient Presenters Decrease Pharmacy Students' Social Distance from Patients with Schizophrenia and Clinical Depression. Am J Pharm Educ 2008;72(5):106-11.

35. Dixon RP, Roberts LM, Lawrie S, Jones LA, Humphreys MS.Medical students' attitudes to psychiatric illness in primary care.Med Educ 2008;42(11):1080-7.

36. Creed F, Goldberg D. Students' attitudes towards psychiatry.Med Educ 1987;21(3):227-34.

37. Wilkinson DG, Greer S, Toone BK. Medical students' attitudes to psychiatry. Psychol Med 1983;13(1):18592. 
38. Baxter H, Singh SP, Standen P, Duggan C.The attitudes of 'tomorrow's doctors' towards mental illness and psychiatry: changes during the final undergraduate year. Med Educ 2001;35(4):381-3.

39. Nordt C, Rossler W, Lauber C. Attitudes of mental health professionals toward people with schizophrenia and major depression. Schizoph Bull 2006;32:709-14

40. Manickam LSS, Rao TSS. Undergraduate medical education : Psychological perspective from India. Indian J Psychiatry 2007;49:175-8.

41. Brockington IF, Hall P, Levings J, Murphy C. The Community's toterance of the mentally ill. Br J Psychiatry 1993;162:93-9.

42. Cumming E, Cumming J. Closed ranks: An experiment in mental health education. Cambridge, MA: Harvard University Press ; 1957.

43. Bhugra D, Scott J. The report of working party of the fourth collegiate trainees' committee. Psychiatr Bull 1989;13:330-3.

44. Angermeyer MC, Holzinger A, Matschinger H. Mental healthliteracy and attitude towards people with mentalillness: A trend analysis based on population surveys in the eastern part of Germany. Eur Psychiatry 2009;24(4):225-32.

Acknowledgment - Department of Psychiatry: B. J. Medical College, Ahmedabad

Source of Funding - None

Conflict of Interest - None 